\title{
Measuring the distribution of adolescent births among 15-19-year- olds in Chile: an ecological study
}

\author{
Marissa Velarde, Fernando Zegers-Hochschild
}

Program of Ethics and Public Policy in Human Reproduction (PREPRE), University Diego Portales, Santiago, Chile

\section{Correspondence to}

Marissa Velarde, Manuel Rodriguez Sur 253, Edificio EA, Santiago, Chile; marissa. velarde@gmail.com

Received 8 April 2015 Revised 23 March 2017 Accepted 8 May 2017 Published Online First 21 June 2017

\section{CrossMark}

To cite: Velarde M, Zegers-

Hochschild F. J Fam Plann

Reprod Health Care

2017:43:302-308.

\begin{abstract}
Background Although within Latin America Chile has one of the lowest birth rates among adolescents, it has a high rate in comparison to other developed nations.

Aim To explore trends in birth rates among adolescents by selected demographics in Chile. Methods The national trend in birth rates was examined for women aged 15-19 years between 1992 and 2012. The birth rates for regions and communes were calculated using birth and census data and were analysed to determine its relationship to the regional or communal poverty rate, which were obtained from the Casen

Survey. Differences in educational attainment were explored among adolescents with firstorder and second-order or higher births using the Chi-square test.
\end{abstract}

Results The birth rate among adolescents has experienced a $25 \%$ decline in the past 20 years. Cross-regional variance in birth rates could not be explained by poverty rates. Within the Metropolitan Region, there is a positive correlation between poverty and adolescent birth rates. Among adolescents giving birth, $67 \%$ had completed $10-12$ years of school at birth, but there is a significant difference in educational attainment between girls with a first-order and those with a higher-order birth. Conclusions In Chile, the adolescent birth rate varies greatly among regions and communes. This study found that urban and wealthy areas had lower birth rates than poor and rural ones, and that girls with a first-order birth had completed more years of school than girls with higher-order births.

\section{INTRODUCTION}

Adolescent pregnancy and parenthood is a global challenge that affects not only the adolescent parent and child, but society as a whole. ${ }^{1}$ Globally and in Chile, adolescents from the poorest households are

\section{Key message points}

- Despite the recent decline in the adolescent birth rate in Chile, it remains high among Organisation for Economic Co-operation and Development (OECD) countries.

- Ecological analysis across the 15 regions of Chile found no correlation between poverty rates and adolescent birth rates.

- However, within the urban province of Santiago, commune birth rate and poverty rate are strongly correlated.

the most likely to experience pregnancy and parenthood, particularly women. ${ }^{12}$ In comparison to women above the age of 20 years, adolescent mothers have a greater risk of experiencing maternal and perinatal morbidity and mortality ${ }^{34}$; they also experience economic and social consequences. A large percentage of Chilean adolescents who are not attending school become pregnant while those in school often abandon their studies after becoming pregnant. ${ }^{5}$ This results in reduced education, fewer job opportunities, and a perpetuation of low socioeconomic status. ${ }^{3}$ The child of an adolescent often experiences social disadvantages that put her/him at greater risk for becoming an adolescent parent, maintaining the intergenerational cycle of adolescent parenthood and poverty. ${ }^{1} 26$ Consequently, adolescent childbearing takes a toll on the economy and the development and growth of a nation. ${ }^{1}$ Indeed, adolescent pregnancy is often seen as an indicator of the level of development of countries. ${ }^{7}$

Chile is one of the most stable countries in Latin America, both economically and socially, and is a member of the Organisation for Economic Co-operation and Development (OECD). ${ }^{8}{ }^{9}$ Within 
the Latin American and Caribbean region, Chile has one of the lowest teen birth rates at around 50 per 1000 girls aged 15-19 years, while the region's overall rate was 67 per 1000 girls in $2012 .{ }^{10}$ However, among the OECD member states, Chile has one of the highest adolescent birth rates compared with 30 and 8 per 1000 girls for USA and Germany, respectively. ${ }^{10}$ Recognising the importance of preventing adolescent pregnancy in the development of the country, Chile has signed many international agreements to promote adolescent sexual and reproductive health and rights, and has made the reduction of the adolescent birth rate a public health priority. ${ }^{11-13}$ This article seeks to assess the situation of adolescent births in Chile as well as the influence of socioeconomic and demographic factors on adolescent fertility.

\section{METHODS}

\section{Population}

This study focused on adolescent girls aged 15-19 years. In 2012, there were 681722 girls in this age category. ${ }^{14}$

\section{Sources of data}

In Chile, the National Institute of Statistics (INE) and the Department of Health Statistics and Information (DEIS) at the Ministry of Health have provided birth data since 1982, which are available to the public. The national birth rates from 1992 to 2011 were obtained from DEIS, while all of the 2012 birth rates were calculated using the vital statistics report and population data from INE. ${ }^{14-16}$ Country and regional population data are available from 2002 to 2012 with estimates for future years. Birth and population data from 2012 for the communes within the Metropolitan Region were provided to the researchers by INE. The 2011 poverty rates, defined as the proportion of people living below the poverty line, were collected from the latest (2011) report on the Survey on National Socioeconomic Characteristics, or Casen Survey, conducted since 1985 every 2-3 years by the Ministry of Social Development. ${ }^{17} 18$ Educational attainment information of mothers was also obtained from the vital statistic report.

\section{Analysis}

The birth rates are presented in the standard way: births per 1000 women aged 15-19 years per year. Statistical analysis was conducted using Microsoft Excel. Weighted average birth rates were calculated for the urban and rural provinces of the Metropolitan Region due to the large difference in population sizes among the communes. Thus, a 'weight' was created for each commune by dividing its female adolescent population by the total female adolescent population in its respective province. Then, the birth rate of each commune was multiplied by its calculated weight. All the birth rates were added up for each of the urban and rural

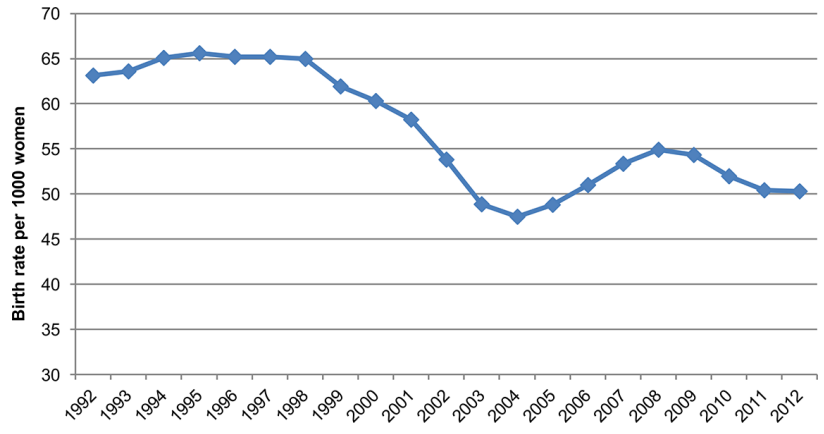

Figure 1 Trend in age-specific birth rate among adolescent women aged 15-19 years in Chile, 1992-2012. Source: Birth Rate Statistics, Department of Health Statistics and Information (DEIS).

provinces to give final weighted average birth rates. The relationship between birth rates and poverty level are assessed by calculating its linear correlation coefficient, $r$, and through linear regression. Differences in years of school attendance according to birth order are presented as counts and proportions and compared using the Chi-square test. Statistical significance was defined as $p<0.05$.

\section{RESULTS}

\section{National}

In 2012, there were 34305 live births to women 15-19 years old, which corresponds to $14.1 \%$ of all live births in Chile. ${ }^{16}$ The age-specific birth rate was 50.3 per 1000 girls aged 15-19 years. As shown in Figure 1, this is a slight decrease from previous years and a $25.5 \%$ decrease from 1992 when the birth rate was 63.2 per 1000 . The average annual percent change was a decrease of $1.2 \%$ each year.

\section{Births by region}

Table 1 contains the birth rates for Chile's 15 administrative divisions, or regions, listed from north to south. It reveals that birth rates among adolescents vary greatly according to where they live. The highest rate was seen in the region of Atacama with a rate of 71.4 per 1000. In fact, the rates for the five most northern divisions were the highest ranging from 60.0 to 71.4 compared with 47 per 1000 in the Metropolitan Region of Santiago. Conversely, the southern region of Biobío, located $500 \mathrm{~km}$ south of the capital city, and Magallanes located in the extreme south of Chile, had among the lowest birth rates for adolescents at 44.0 and 47.6 per 1000 , respectively.

\section{Births by poverty rate}

Table 1 also details the poverty rate for each region. Despite having the highest birth rate, Atacama had a lower poverty rate, at $16.3 \%$, than the overall rate of $22.2 \%$, as well as being lower than most regions. Meanwhile, Biobío had the lowest birth rate, in spite of a poverty rate of $32.2 \%$, which is greater than the overall rate. The relationship between regional adolescent birth rate and poverty level is displayed in 
Table 12011 poverty rates and birth rates for adolescent women aged 15-19 years by region within Chile, 2012. Regions are listed north to south

\begin{tabular}{|c|c|c|c|}
\hline Region & $\begin{array}{l}\text { Poverty } \\
\text { rate (\%), } \\
2011\end{array}$ & $\begin{array}{l}\text { Birth rate } \\
\text { (per } 1000 \\
\text { women) }\end{array}$ & $\begin{array}{l}\text { Population of } \\
\text { women aged } \\
15-19 \text { years }\end{array}$ \\
\hline Arica \& Parinacota & 21.0 & 60.0 & 8749 \\
\hline Tarapacá & 16.4 & 69.4 & 12028 \\
\hline Antofagasta & 7.1 & 64.1 & 23324 \\
\hline Atacama & 16.3 & 71.4 & 12140 \\
\hline Coquimbo & 26.1 & 63.0 & 30457 \\
\hline Valparaíso & 24.5 & 50.8 & 67395 \\
\hline Metropolitan & 15.7 & 47.0 & 263091 \\
\hline L.B. O'Higgins & 19.4 & 48.9 & 36564 \\
\hline Maule & 32.5 & 47.9 & 41869 \\
\hline Biobío & 32.3 & 44.0 & 84759 \\
\hline Araucanía & 39.7 & 51.6 & 41729 \\
\hline Los Ríos & 32.0 & 54.5 & 16571 \\
\hline Los Lagos & 27.0 & 54.2 & 33010 \\
\hline Aysén & 13.3 & 54.3 & 4240 \\
\hline Magallanes & 7.0 & 47.6 & 5796 \\
\hline Overall & 22.2 & 50.3 & 681722 \\
\hline
\end{tabular}

Source: Casen Survey 2013: The Poverty Situation in Chile, Ministry of Social Development, 2014

Figure 2. The scatter plot shows a weak negative correlation $(r=-0.3)$, which is not statistically significant $(p>0.2)$.

The lack of a significant relationship between poverty and adolescent births among regions could be the result of several confounding factors. For this reason it is useful to stratify within a region.

\section{Births by commune}

The Metropolitan Region contains the majority of the population of Chile, $40.3 \%$ of Chileans reside here. ${ }^{19}$ This area has socioeconomically segregated communes, allowing for a better analysis of the relationship

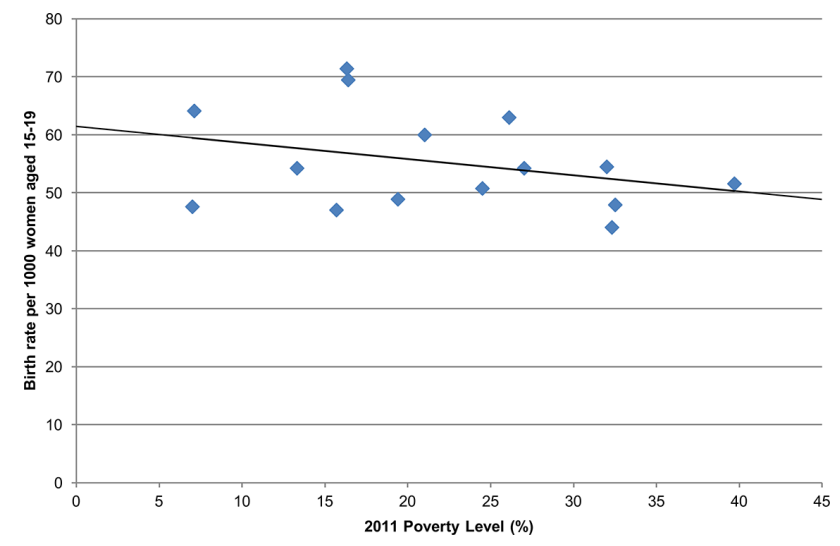

Figure 2 Adolscent birth rates and poverty levels among regions in Chile, 2012. Source: Casen Survey 2013: The Poverty Situation in Chile, Ministry of Social Development, 2014. between poverty levels and adolescent birth rates. ${ }^{20}$ As shown in Table 2, the Metropolitan Region comprises a total of 52 communes distributed within six provinces. ${ }^{19}$ The Santiago province is primarily urban while the remaining provinces are mainly rural. The table also shows the adolescent birth rates and poverty rates in all the communes of the Metropolitan Region. The rural provinces have a weighted average birth rate of 57.5 per 1000 girls, while the weighted average is 43.4 per 1000 for the urban province. Vitacura, Providencia and Las Condes are the richest communities with a poverty level of only $0.2 \%$ and $2.3 \%$ and also have the lowest birth rates at 2.9, 7.3, and 7.1 per 1000, respectively. Conversely, Tiltil and San Pedro are the poorest with poverty rates around $32 \%$ and have higher adolescent birth rates at 57.1 and 54.2 per 1000, respectively.

Figure 3 displays the relationship between poverty and the adolescent birth rate for the Metropolitan Region, and overall shows a trend for higher birth rates in communes with higher poverty levels. A simple analysis across all 52 communes reveals a direct and fairly strong linear correlation $(r=0.6, p<0.001)$. However, the relationship between poverty and birth rate differs between the urban and rural provinces, which have been plotted using different markers to highlight this difference. The birth rates for the 20 rural communes are fairly level across poverty levels, suggesting there is no correlation, as is confirmed by analysis $(r=0.1$, $p=0.66$ ). In contrast, there is greater spread among the 32 urban communes in poverty levels (from close to $0 \%$ to $31 \%)$, and a strong linear correlation between poverty and birth rates $(r=0.7, p<0.001)$.

\section{Educational attainment}

Among adolescents giving birth, approximately 40.4\% were currently students, and $67 \%$ had completed between 10 and 12 years of school, or secondary education in 2012. Table 3 shows that adolescents with a second- or higher-order birth have attended fewer years of school compared with those with a first-order birth, a difference that is significant $(p<0.001)$. Only $51.3 \%$ of those with second- or higher-order births had attended more than 10 years of school, compared with $73.3 \%$ of girls having a first-order birth.

\section{DISCUSSION}

Globally, girls are more likely to become pregnant if they are poor, live in rural areas, and have little education. ${ }^{1}$ Our study suggests that the situation in Chile does not quite follow this global trend. A regional analysis reveals that there is no correlation between the regional poverty rate and its adolescent birth rate. Within the Metropolitan Region, there is a correlation between these two variables among urban communes but not rural communes. Regarding education, slightly fewer than half of adolescent girls were registered as students at the moment of delivery. Those experiencing 
Table 22011 poverty rates and birth rates for adolescent women aged 15-19 years by commune within the Metropolitan Region, 2012

\begin{tabular}{|c|c|c|c|}
\hline Commune & Poverty rate (\%), 2011 & $\begin{array}{l}\text { Birth rate (per } 1000 \\
\text { women) }\end{array}$ & $\begin{array}{l}\text { Population of women } \\
\text { aged } 15-19 \text { years }\end{array}$ \\
\hline \multicolumn{4}{|c|}{ Santiago Province (Urban) } \\
\hline Cerrillos & 15.1 & 52.8 & 2971 \\
\hline Cerro Navia & 19.8 & 56.7 & 5907 \\
\hline Conchalí & 11.4 & 57.6 & 4861 \\
\hline El Bosque & 16.0 & 50.7 & 7687 \\
\hline Estación Central & 20.6 & 45.5 & 4725 \\
\hline Huechuraba & 15.0 & 47.7 & 3334 \\
\hline Independencia & 13.7 & 44.7 & 2417 \\
\hline La Cisterna & 12.6 & 32.6 & 3221 \\
\hline La Florida & 12.1 & 29.8 & 15792 \\
\hline La Granja & 18.3 & 57.2 & 5825 \\
\hline La Pintana & 19.4 & 68.5 & 9611 \\
\hline La Reina & 11.3 & 13.4 & 3950 \\
\hline Las Condes & 2.3 & 7.1 & 9755 \\
\hline Lo Barnechea & 15.4 & 16.5 & 4370 \\
\hline Lo Espejo & 24.0 & 58.0 & 4760 \\
\hline Lo Prado & 13.1 & 58.0 & 3842 \\
\hline Macul & 9.7 & 38.4 & 4032 \\
\hline Maipú & 14.2 & 39.9 & 21532 \\
\hline Ñuñoa & 7.1 & 16.2 & 6304 \\
\hline Pedro Aguirre Cerda & 17.9 & 54.9 & 4371 \\
\hline Peñalolén & 19.1 & 55.2 & 9053 \\
\hline Providencia & 0.2 & 7.3 & 3823 \\
\hline Pudahuel & 17.3 & 55.9 & 9123 \\
\hline Quilicura & 12.4 & 55.7 & 7435 \\
\hline Quinta Normal & 15.2 & 58.2 & 3657 \\
\hline Recoleta & 13.9 & 52.4 & 5616 \\
\hline Renca & 23.2 & 77.4 & 5747 \\
\hline San Joaquín & 30.8 & 46.1 & 3495 \\
\hline San Miguel & 16.6 & 22.4 & 3265 \\
\hline San Ramon & 19.4 & 72.6 & 3512 \\
\hline Santiago & 12.3 & 37.6 & 8187 \\
\hline Vitacura & 0.2 & 2.9 & 3084 \\
\hline \multicolumn{4}{|c|}{ Cordillera, Talagante, Maipo, Melipilla, and Chacabuco Provinces (Rural) } \\
\hline Alhué & 13.9 & 74.3 & 202 \\
\hline Buin & 15.2 & 56.1 & 3190 \\
\hline Calera de Tango & 13.0 & 50.7 & 868 \\
\hline Colina & 15.3 & 64.4 & 4180 \\
\hline Curacaví & 24.4 & 55.9 & 1091 \\
\hline El Monte & 10.3 & 58.2 & 1340 \\
\hline Isla de Maipo & 19.5 & 55.9 & 1270 \\
\hline Lampa & 29.1 & 70.1 & 2911 \\
\hline María Pinto & 24.0 & 46.9 & 490 \\
\hline Melipilla & 22.3 & 55.2 & 4381 \\
\hline
\end{tabular}


Table 2 Continued

\begin{tabular}{|c|c|c|c|}
\hline Commune & Poverty rate (\%), 2011 & $\begin{array}{l}\text { Birth rate (per } 1000 \\
\text { women) }\end{array}$ & $\begin{array}{l}\text { Population of women } \\
\text { aged } 15-19 \text { years }\end{array}$ \\
\hline Padre Hurtado & 13.6 & 52.0 & 1904 \\
\hline Paine & 18.6 & 62.9 & 2337 \\
\hline Peñaflor & 13.9 & 63.0 & 3046 \\
\hline Pirque & 12.4 & 46.1 & 759 \\
\hline Puente Alto & 22.3 & 51.9 & 23930 \\
\hline San Bernardo & 24.6 & 64.9 & 11626 \\
\hline San José de Maipo & 13.3 & 41.3 & 508 \\
\hline San Pedro & 32.2 & 54.2 & 295 \\
\hline Talagante & 9.6 & 58.9 & 2868 \\
\hline Tiltil & 32.2 & 57.1 & 631 \\
\hline
\end{tabular}

Sources: Birth and population data for 2012 provided by National Institute of Statistics (INE); Casen Survey 2013: Estimates of Poverty According to Income in Communes, Ministry of Social Development, 2014.

a second- or higher-order birth were significantly more likely to have fewer years of education.

We found that the adolescent birth rate in Chile was lower in 2012 than in recent years, and considerably lower than 20 years ago. Nevertheless, for the past 20 years adolescent births in Chile have remained around $15 \%$ of all births. ${ }^{15}$ This percentage is greater than the country's Millennial Development Goal (MDG), to reduce the proportion of adolescent births to $8.9 \%$ by $2015 .^{13}$ A similar experience is seen throughout the Latin American and Caribbean region, where the proportion of teen births has remained constant or increased. ${ }^{121}$

Chile's adolescent birth rate is among the lowest in the region, but it is not straightforward to compare its pregnancy rate to other countries. Pregnancy rates are calculated as the sum of births, abortions, stillbirths and miscarriages. Abortion is illegal under all circumstances in Chile, whereas in countries where abortion is legal, including USA and Germany, the adolescent birth rate is much lower than its pregnancy

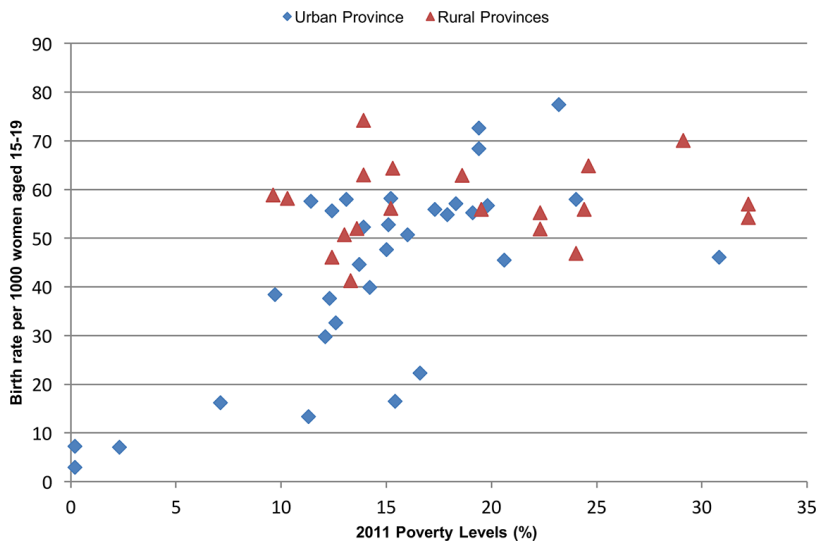

Figure 3 Adolscent birth rates and poverty levels among communes categorised by urban and rural provinces in the metropolitan region, 2012. Source: Casen Survey 2013: Estimates of Poverty According to Income in Communes, Ministry of Social Development, 2014. rate because many unintended adolescent pregnancies are terminated. Furthermore, the fact that abortion in Chile is illegal means there is unreliable information on its incidence. ${ }^{7223}$ Thus, the adolescent pregnancy rate is likely to be higher than reported.

Our study showed no significant relationship between poverty levels and adolescent birth rates when analysing regional differences in Chile. However, the poverty rate variable used is binary; it is a threshold indicator of the proportion living in extreme poverty. Such a variable does not distinguish between the moderately impoverished, and other more affluent socioeconomic groups. It could be that the risk of adolescent births is greatest among populations who are at least moderately impoverished. If this is the case, the (extreme) poverty rate is not an optimum indicator of risk, since it does not reflect the proportion who are at least moderately impoverished. This could explain the lack of relationship between regional poverty levels and birth rates, particularly in the northern regions where the presence of the mining industry has been able to lift the local population out of extreme poverty, but not necessarily out of moderate impoverishment.

Regional variance in adolescent births could also be explained by the rural/urban variable. Biobío and the

Table 3 Years of school attended among adolescent women according to first-order birth and second- or higher-order birth, Chile, $2012\left(n=34276^{*}\right)$

\begin{tabular}{lllll}
\hline \multirow{4}{*}{ Birth order } & \multicolumn{4}{l}{ School attendance (years) } \\
\cline { 2 - 5 } & $\mathbf{0 - 6}$ & $\mathbf{7 - 9}$ & $\mathbf{1 0 - 1 2}$ & $\mathbf{1 3 +}$ \\
\hline First & 531 & 7573 & 21053 & 1208 \\
& $(1.7 \%)$ & $(24.9 \%)$ & $(69.3 \%)$ & $(4.0 \%)$ \\
Second or higher & 238 & 1667 & 1933 & 73 \\
& $(6.1 \%)$ & $(42.6 \%)$ & $(49.4 \%)$ & $(1.9 \%)$ \\
\hline
\end{tabular}

*N/A responses were not included.

Source: Vital Statistics, Annual Report 2012, National Institute of Statistics (INE), 2014 
Metropolitan Region had the lowest birth rates and are also the urban regions with the largest densities of people in the country. ${ }^{16}$ This finding is in accordance with local reports which indicate that rural areas of Chile have a higher adolescent birth rate than corresponding urban zones. $^{11}$

To minimise the influence of confounding factors, such as access to reproductive health services, a within-regional analysis was conducted for the Metropolitan Region. This commune-level assessment showed a positive correlation between poverty rate and adolescent births. Yet, the linear regression explains only $34.3 \%$ of the variance in the teenage birth rate. This is in part due to a lack of relationship with poverty rate among rural provinces, where the adolescent birth rate is relatively high regardless of poverty rate. Among urban communes, the linear regression accounts for $50 \%$ of the variance in the teenage birth rate, which is more predictive but indicates there is still unexplained variation. It is of note that among urban communes with poverty rates between $9.7 \%$ to about $15.2 \%$, the adolescent birth rates range from 13.4 to 58.2 per 1000 . This suggests that there could be other variables affecting the adolescent birth rate, such as education and access to family planning. It could also be because the poverty variable indicates only prevalence of extreme poverty, and not the proportion of those who are at least moderately impoverished, as previously discussed.

Evidence indicates that low-income and rural adolescents experience greater vulnerability to pregnancy due to interrupted schooling, a lack of knowledge about sexual and reproductive health, lower use of contraception, and limited availability/barriers to accessing reproductive health services that are teen-friendly. ${ }^{11}{ }^{12}{ }^{21}$ In fact, the Chilean youth health survey revealed that youths from high-income families are more likely to use a contraceptive method during the first sexual encounter than their middle- and low-income peers $(76.1 \%$ vs $50.2 \%$ and $39.3 \%$, respectively). ${ }^{24}$

There are no recent data on the education attainment of girls who do not experience childbearing before age 20 years. However, results from the Chilean youth survey show that $81 \%$ of adolescents aged $15-19$ years were attending school, which is double the proportion of girls that were students at delivery. ${ }^{25}$ It is difficult to determine if school abandonment preceded or followed pregnancy. Similarly, it cannot be assumed that girls have abandoned their education altogether as they might return to school postpartum. Although a large percentage of girls had completed some high school at the time of delivery, this study found that girls with a first-order birth had significantly more years of schooling than those with higher-order births. Nevertheless, both groups of adolescent mothers are at risk for experiencing limited economic opportunities. Research has shown that adolescent motherhood is associated with lower earnings, particularly among poor Chilean women, entrenching them in poverty. ${ }^{26}$ Furthermore, our findings indicate that there is a need for family planning among first-time mothers in order to prevent additional pregnancies during adolescence.

There were limitations to the present study. The analyses undertaken are ecological correlations, since the correlations calculated are based on data from a group of people, rather than individual-level data. As such, this is a descriptive study that suggests individual factors may be important. However, our research can make only ecological inferences, with the well-known risk of confounding and aggregation biases. ${ }^{27}$ There is also a problem with directionality; that is, this analysis cannot address the extent to which poverty and low education are causes or consequences of adolescent pregnancy, nor establish what other factors are also implicated.

Our study focused on a few, general factors that might be associated with adolescent birth rates, but there are a large number of social, cultural, political and individual factors that influence adolescent pregnancy and birth. Further research should focus on individual determinants of pregnancy, including contraceptive behaviour, family and peer contexts, education, cultural and religious beliefs, and access to reproductive health services. It is also important to investigate the causes and consequences of adolescent parenthood among Chilean boys since very few studies address this topic and data are scarce. ${ }^{711} 1228$ The literature has shown that adolescent fathers can also be negatively affected by paternity and experience similar adverse consequences to girls. ${ }^{7} 28$ Further research can help identify and develop evidencebased public policies for the prevention of adolescent pregnancies and births.

Findings from this study reveal that the adolescent birth rate varies widely throughout Chile according to geographical location, but the reasons for this observed variance are not clear. Within the Santiago province, the commune-level poverty might explain the variance. Research in Latin America indicates that the highest rates of adolescent births occur in the poorest regions and populations. ${ }^{21}$ Similarly, global data show that differences within a country may be the result of differences in income, education and inequitable access to health services. ${ }^{1}$ We also found that first-time adolescent mothers had significantly more years of education than girls with subsequent pregnancies. It appears that the prevalence of adolescent childbearing reflects the social inequalities present in Chilean society and may contribute to its maintenance. ${ }^{11}$

This research suggests that strategies to lower the adolescent birth rate should include promoting education among girls and ensuring widespread access to contraception, and perhaps also reducing poverty, or associated factors. In doing so, Chile can meet several targets of the Sustainable Development Goals (SDGs) formally adopted by the United Nations at the end of $2015 .^{29}$

Correction notice This paper has been amended since it was published Online First. Owing to a scripting error, some of the publisher names in the references were replaced with 'BMJ Publishing Group'. This only affected the full text version, not the PDF. We have since corrected these errors and the correct publishers have been inserted into the references. 
Acknowledgements The authors would like to thank Dr Patrick Rowe, Dr Sofia Salas, and Enzo Cordova for their guidance and assistance. They would also to thank the statistical reviewer of the Journal of Family Planning and Reproductive Health Care for their valuable additions to the analysis and presentation of the study findings.

Competing interests None declared.

Provenance and peer review Not commissioned; externally peer reviewed.

(C) Faculty of Sexual and Reproductive Healthcare of the Royal College of Obstetricians and Gynaecologists (unless otherwise stated in the text of the article) 2017. All rights reserved. No commercial use is permitted unless otherwise expressly granted.

\section{REFERENCES}

1 UNFPA. State of the World Population 2013. Motherhood in Childhood: facing the challenge of adolescent pregnancy. http://www.unfpa.org/sites/default/files/pub-pdf/ENSWOP2013-final.pdf (accessed Dec 2014).

2 Olavarría J. Sexualidad Adolescente: embarazos. maternidad, paternidad. La Larga espera para un abordaje en serio. Rev Docencia 2013;49:62-75.

3 World Health Organization (WHO). Adolescent pregnancy. 2014 http://www.who.int/mediacentre/factsheets/fs364/en/ (accessed Dec 2014).

4 Donoso E, Carvajal JA, Vera C, et al. La edad de la mujer como factor de riesgo de mortalidad materna, fetal, neonatal e infantil. Rev Med Chil 2014;142:168-74.

5 Molina S M, Ferrada N C, Pérez V R, et al. Embarazo en La Adolescencia Y su relación con la deserción escolar. Rev Med Chil 2004;132:65-70.

6 González A E, Leal F I, Molina G T, et al. Patrón intergeneracional del embarazo adolescente en las hijas de Una cohorte de mujeres que controlaron su primer embarazo en un centro integral para adolescentes embarazadas. Rev Chil Obstet Ginecol 2013;78:282-9.

7 Molina RC, Roca CG, Zamorano JS, et al. Family planning and adolescent pregnancy. Best Pract Res Clin Obstet Gynaecol 2010;24:209-22.

8 OECD. OCDE 360 Chile 2015 ¿en qué situción está Chile Comparativamente? http://www.oecd360.org/oecd360/chile\# (accessed Aug 2015).

9 Programa de Naciones Unidas para el Desarrollo (PNUD). Chile en Breve.. 2014 http://www.cl.undp.org/content/chile/es/ home/countryinfo/ (accessed 14 August 2015).

10 United Nations (UN) Data. Adolescent fertility rate (births per 1,000 women aged 15-19. http://data.un.org/Data.aspx?d=WDI\& $\mathrm{f}=$ Indicator_Code\%3ASP.ADO.TFRT (accessed 2 June 2016).

11 Dides C, Benavente M, Moran J. Diagnóstico de la situación del embarazo en la adolescencia en Chile, 2008: Gobierno de Chile Ministerio de Salud, UNFPA, FLACSO-Chile, 2008. http://issuu.com/flacso.chile/docs/embarazo_adolescente. (accessed 14 August 2015).

12 Ministerio de Salud Gobierno de Chile. Situación Actual de Embarazo Adolescente en Chile. 2013 http://web.minsal.cl/ portal/url/item/c908a2010f2e7dafe040010164010db3.pdf (accessed 21 August 2014).

13 Naciones Unidas, Goberierno de Chile. Objetivos De Desarrollo de Milenio, Cuarto Informe Del Gobierno de Chile. 2014 http:/ /observatorio.ministeriodesarrollosocial.gob.cl/layout/doc/ODM/ Cuarto_Informe_ODM.pdf (accessed 14 August 2015).
14 Instituto Nacional de Estadisticas (INE). Anuario De Estadísticas Vitales 2012. 2014 http://www.ine.cl/canales/menu/ publicaciones/calendario_de_publicaciones/pdf/completa_ vitales_2012.pdf (accessed 22 August 2014).

15 Departamento de Estadisticas e Informacion de Salud (DEIS). Tasa Específica de Fecundidad, 1992-2011. 2014 http://www. deis.cl/wp-content/uploads/2014/01/Tasa-espec\%C3\%ADficade-fecundidad.-Chile-1992-2011.xlsx (accessed 22 August 2014).

16 Instituto Nacional de Estadisticas (INE). Población, País, y Regiones: Actualización Población 20022012 y Proyecciones 2013-2020.2014http://www.ine.cl/canales/chile_estadistico/ demografia_y_vitales/proyecciones2014/proyecciones-depoblacion-2014.xlsx(accessed 22 August 2014)

17 Ministerio de Desarrollo Social. Encuesta Casen 2013: situación De La Pobreza en Chile. 2014 http://observatorio. ministeriodesarrollosocial.gob.cl/documentos/Casen2013 Situacion_Pobreza_Chile.pdf (accessed 14 August 2015).

18 Ministerio de Desarrollo Social. Estimaciones de Taza de Pobreza por Ingresos por Comunas - 2011. 2014 http://observa torio.ministeriodesarrollosocial.gob.cl/documentos/Estimacion_ tasa_de_pobreza_comunal_2011_(nueva_metodologia).xlsx.zip (accessed 22 August 2015).

19 Intendencia Región Metropolitana, Ministerio del Interior y Seguridad Pública. Información Geográfica. http://www. intendenciametropolitana.gov.cl/informacion_geografica_2. html (accessed 1 September 2015).

20 Agostini C, Brown P. Desigualdad geográfica en Chile. Rev Anal Econ 2007;22:3-33.

21 Gomes C. Adolescent fertility in selected countries of Latin America and the Caribbean. J Public Health Epidemiol 2012;4:133-140.

22 Molina-Cartes R, Molina T, Carrasco X, et al. Profile of abortion in Chile, with extremely restrictive law. Open J Obstet Gynecol 2013;03:732-738.

23 Shepard BL, Casas Becerra L. Abortion policies and practices in Chile: ambiguities and dilemmas. Reprod Health Matters 2007;15:202-210.

24 Instituto Nacional de la Juventud (INJUV), Gobierno de Chile. 6ta Encuesta Nacional de Juventud 2009. 2010 http:// www.injuv.gob.cl/portal/wp-content/files_mf/sextaencuestanac ionaldejuventud.pdf (accessed 15 August 2014).

25 Instituto Nacional de La Juventud (INJUV), Gobierno de Chile. 7ma Encuesta Nacional de Juventud 2012. 2013 http:// www.injuv.gob.cl/portal/wp-content/files_mf/septimaencuestana cionainjuvcorr2.pdf (accessed 15 August 2014).

26 Buvinic M. The costs of adolescent childbearing: evidence from Chile, Barbados, Guatemala, and Mexico. Stud Fam Plann 1998;29:201-209.

27 Freedman D. Ecological Inference and the Ecological Fallacy (prepared for the International Encyclopedia of the Social \& Behavioral Science). Berkeley, CA: University of California, 1999. http://web.stanford.edu/class/ed260/freedman549.pdf. (accessed 21 March 2016).

28 González E, Toledo V, Luengo X, et al. Paternidad Adolescente II: variables familiares e impacto de la paternidad en el padre adolescente. Rev Soc Chil Ginecol Infantil Adolesc 1999;6:51-59.

29 United Nations. Sustainable Development Goals. http://www.u n.org/sustainabledevelopment/sustainable-development-goals/ (accessed 21 March 2016). 